\title{
The Compatibility of a GIS Map of Landslide-Prone Areas in Kendari City Southeast Sulawesi with Actual Site Conditions
}

\author{
Andri Estining Sejati ${ }^{1,}$, Ahmad Tarmizi Abd Karim ${ }^{2}$, Akbar Tanjung ${ }^{3}$ \\ ${ }^{1}$ Geography Education Universitas Sembilanbelas November Kolaka, Street Pemuda Number 399 \\ ${ }^{2}$ Civil and Environmental Engineering Universiti Tun Hussein Onn Malaysia, 86400 Parit Raja-Johor- \\ Malaysia \\ ${ }^{3}$ Geography Education Universitas Halu Oleo, Anduonohu-Kendari \\ *) Corresponding Author (e-mail: andriest@usn.ac.id)
}

Received: 22 March 2020/Accepted: 13 June 2020/Published: 17 June 2020

\begin{abstract}
Kendari is the capital of the Indonesian province of Southeast Sulawesi. It is mainly located in a region of karst hills, with high rainfall and numerous human activities taking place on the hills. Many landslides have occurred in the area, with natural and human factors contributing to these. The purpose of this study is to determine whether the present GIS map of the landslideprone areas corresponds to and is compatible with the actual site conditions in Kendari City. The research is mainly a regional survey, with data collected through direct interviews and observation at the sites. The data was analysed quantitatively in percentage terms. The results show that $87.4 \%$ of the area, as shown on the landslide-prone distribution map using GIS, was included in the low risk, or slightly vulnerable, category. The categories of landslide-prone areas are divided into very low risk, low, medium and high risk, and very high risk, representing the range from less vulnerable areas to very vulnerable ones. The level of compatibility of landslide-prone map of Kendari City when compared with actual site conditions is 75\%. This shows that the GIS spatial analysis map can be used as a guide in mapping the level of landslide vulnerability in the area. The map of landslide-prone areas could be used as a guideline for engineers, designers, planners, and city officials in planning to reduce the risk of potential disaster.
\end{abstract}

Keywords: compatibility, map, landslide-prone, risk, vulnerability

\section{Introduction}

Landslides often links environmental and regional approaches to spatial contexts. The spatial context in the landslides phenomenon is discussed can be approached through Geographic Information Systems (GIS) as geography describes the Earth and enhancing science. A GIS can provide geospatial data information about landslides quickly with accurate spatial analysis. According to Nurdin \& Kubota (2018), GIS based-landslide mapping assess the landslide area with causative factors and can give information about landslide susceptibility area.

GIS-based landslide mapping is a system created to integrate vectors, raster, and attributes of spatial data related to landslide such as rainfall-based map in form of vectors, road in form of polyline shapefile raster data, and the border attributes information in form of spatial data attributes. The main GISbased landslide capability in spatial contexts is spatial analysis in landslide digital maps. According to Hadmoko et al. (2017) spatial analysis conducted landslides triggering from the causative factor. According to Guzzetti et al (2012) in an inventory map landslide information is shown as a combination of points, polylines, and polygons.

GIS-based landslide mapping can connect various data at certain points on the earth, combining, analysing, and mapping the results. Data that are processed in GISbased landslide are spatial reference data or geographically oriented with a coordinate system. GIS-based landslide can answer several geographic questions, one of which is related to landslide zones in certain areas. 
According to Shahabi \& Hashim (2015), GISbased landslide mapping can reach an accuracy of above $89 \%$.

Natural disasters are a consequence of a combination of natural and human activities. One type of natural disasters that often occurs in Indonesia are landslide. Data (BNPB, 2019) show that landslides constituted 1483 of the 9383 disasters year 2019 in the country, or $15.8 \%$. They can be triggered from a combination of factors, namely rainfall, soil type, slope, and land use. If the slope is steep, with extreme weather, high clay content and poor ability to absorb rainfall, and with little or no vegetation on the sloping land, the area will be prone to landslides. The mapping of landslide zones is therefore important for community preparedness in anticipating the impact of landslides. According to Hartono \& Nasikh (2017), the determinants of landslides are soil type, slope, land use, and heavy rainfall.

Landslides are natural disasters that can cause casualties and material losses, the latter including silting of rivers, potential flooding of watersheds, and damage to agricultural land, settlements, traffic lanes, bridges, irrigation channels, and area of tourist interest. According to Qarinur (2015), landslides can affect the surrounding area. Ruiz-Villanueva et al. (2017), also stated that landslide on the slopes of the Himalayan mountains can lead to flooding in the lower regions. In addition Najib et al. (2015), emphasise that the consequence of landslides is the destruction of people's homes, while Amaluddin et al. (2019), stated that one way of identifying a good tourism location is frequency disaster that occur there.

The topography of the capital of Southeast Sulawesi Province, Kendari City is an area consisting mainly of karst hills. The city has a fairly high rainfall in the rainy season. Settlement activities, karst hill mining, the opening of new roads, and the widening of existing roads with heavy equipment, all of which are abundant in this area, can erode the hills. According to Rahman et al. (2014), human activity on natural slopes can accelerate landslides. Suwarno et al. (2016) suggested that the level of education, knowledge, information, and the economy affects the community, particularly in land management on high slopes, and also suggested that the hilly environment it should be maintained. In addition, Hadmoko et al. (2017) stated that conversion of forests to rice fields is the main cause of landslides in Java.

The Regional Disaster Management Agency (BPBD) (2012) landslide zone map shows that landslides on a medium to high scale can occur in almost all of Kendari City, particularly in areas bordering Konawe and South Konawe, and half of the central residential area. However, this 2012 map requires improvement and updating with recent data/information.

In this research, the mapping of landslideprone areas in Kendari City using GIS was updated to 2019. Landslides from causative factors, namely rainfall, soil type, slope, and land use were processed in GIS-based landslide mapping with spatial analysis. The spatial analysis used in this research was overlay. Furthermore, the 2012 map was updated with the actual site conditions to determine its usability before it was published. Mueller et al. (2015), suggested that disaster map should be updated by GIS with new information. The purpose of this research is to determine whether the present GIS map of landslide-prone areas is in agreement and compatible with actual conditions in Kendari City

\section{Research Method}

The field survey was conducted in January 2019 to determine the compatibility of a map of landslide-prone areas in the Kendari City with actual site conditions. The location was sampled using the purposive sampling method, with 28 sample points based on the 2017 General Disaster Report data obtained from the Kendari City BPBD. According to Kovács et al. (2019), field survey is one method to ascertain the level of landslides in an area.

Map of landslide-prone areas that are used as references for conformity are produced using the overlay method with scoring and weighting. Table 1 , Table 2, Table 3, and Table 4 shows the scores and the weights of each parameter. 
Table 1. Rainfall Scoring and Weighting

\begin{tabular}{cccccc}
\hline Nu. & Rainfall (mm/month) & Classification & Weight & Score & $\sum$ Value \\
\hline 1 & $>301$ & High & 10 & 0.4 & 4 \\
2 & $101-300$ & Medium & 10 & 0.3 & 3 \\
3 & $0-100$ & Low & 10 & 0.2 & 1 \\
\hline
\end{tabular}

Source: Purba et al. (2014)

Table 2. Soil Type Scoring and Weighting

\begin{tabular}{cccccc}
\hline Nu. & Soil Type & Classification & Weight & Score & $\sum$ Value \\
\hline 1 & Andosol & High & 20 & 0.4 & 8 \\
2 & Mediterranean & Medium & 20 & 0.3 & 6 \\
3 & Alluvial, latosol, grumusol & Low & 20 & 0.2 & 4 \\
\hline
\end{tabular}

Source: Purba et al. (2014)

Table 3. Slope Scoring and Weighting

\begin{tabular}{cccccc}
\hline Nu. & Slope (\%) & Classification & Weight & Score & $\sum$ Value \\
\hline 1 & $0-8$ & Flat & 40 & 0.02 & 0.8 \\
2 & $8-15$ & Declivous & 40 & 0.07 & 2.8 \\
3 & $15-25$ & Medium & 40 & 0.15 & 6 \\
4 & $25-40$ & Steep & 40 & 0.32 & 12.8 \\
5 & $>40$ & Very Steep & 40 & 0.45 & 18 \\
\hline
\end{tabular}

Source: Purba et al. (2014)

Table 4. Land Use Scoring and Weighting

\begin{tabular}{cccccc}
\hline Nu. & Land Use & Classification & Weight & Score & $\sum$ Value \\
\hline 1 & Moor & Poor & 30 & 0.38 & 11.4 \\
2 & Plantation & Very low & 30 & 0.25 & 7.5 \\
3 & Mixed Plantation & Low & 30 & 0.21 & 6.3 \\
4 & Settlement, Building & Moderate & 30 & 0.09 & 2.7 \\
5 & Land Farming & High & 30 & 0.06 & 1.8 \\
6 & Forest & Very High & 30 & 0.01 & 0.3 \\
\hline \multicolumn{5}{c}{ Source: Purba et al. (2014) }
\end{tabular}

The data sources used were the classification of slopes by the Geospatial Information Agency (BIG) (2016); the BIG soil type (2016); Meteorology, Climatology and Geophysics Agency (BMKG) rainfall data from the Kendari City Maritime Station (2018); and the land use data from the Department of Public Works (PU) of Southeast Sulawesi Province (2018). The parameters in the form of weights and scores were similar to those of Purba et al. (2014). All parameters were overlaid with the classification of landslides by determining the class interval of landslide hazard-prone levels, using five classifications: very low, low, medium, high risk, and very high risk, representing the less vulnerable to the very vulnerable areas using the arithmetic method (Dawood, 2011; Dawood \& Dawood, 2019) with the following formula.

$$
K_{i}=\frac{K_{t}-K_{r}}{K}
$$

where $K_{\mathrm{i}}$ is the interval class; $K_{\mathrm{t}}$ is the highest data; $K_{r}$ is the lowest data; $K$ is the number of classes. The data is sum of score.

The data were collected using the field survey techniques, by direct observation at the sites, and through interviews with the villagers and government representatives of Kendari City BPBD. The interviews served to complement the information on the occurrence of landslides in the research area. The data were 
analysed quantitatively using percentages. In areas on the map similar to the actual site conditions, a value of 1.0 was given, while if they were non-compatible, they were given a value of 0.0 . The final value was divided by the total number of samples to determine the suitability level.

\section{Results and Discussion}

\subsection{Result}

Kendari city has a monthly average rainfall of $175.88 \mathrm{~mm}$ and is therefore included in the medium class category. The rainfall weight is 10 , with a score of 0.3 , so the results from the multiplication of weights is 3.0. Huang et al. (2012) state that rainfall of more than $2500 \mathrm{~mm}$ per year is a potential cause of landslides.

Almost $34.5 \%$ of soil types in Kendari city consist of low humid glei, alluvial, acid sulfidic acid, gray-brown podsolic, and latosol soil of moderate erodibility. The soil type weight is moderate, 20, with a score of 0.3 , giving a weight multiplication results of 6.0. The highweighted soil consists of regosol and latosol, which is quantitatively estimated to be $27.9 \%$. This soil type weight is also moderate, at 20, with a score of 0.4 , so the weight multiplication results is 8.0. According to Qarinur (2015), when exposed to rainwater type of soil determines whether a landslide could occurs. In addition, Nursalam et al. (2019) state that soil structure is affected by geological conditions.

The slope angle is the most significant factor in the occurrence of landslide; an angle of $15-25^{\circ}$ in this research was quantitatively estimated to be $30.6 \%$. The weight attributed to steep slope was 40 , with a score of 0.15 , so the results of the multiplication of weights was 6.0. Najib et al. (2015) state that a slope above $10^{\circ}$ is a condition for landslides to occur.

Table 5. Results of Determining Interval Class Category of landslide Prone Areas in Kendari City

\begin{tabular}{ccc}
\hline Nu. & Class Interval & Landslide-prone category \\
\hline 1 & $9.6-14.72$ & Very Low (Less vulnerable) \\
2 & $14.73-19.84$ & Low (Slightly vulnerable) \\
3 & $19.85-24.96$ & Medium (Moderately vulnerable) \\
4 & $24.7-30.08$ & High Risk (Vulnerable) \\
5 & $30.09-35.2$ & Very High Risk (Very vulnerable) \\
\hline
\end{tabular}

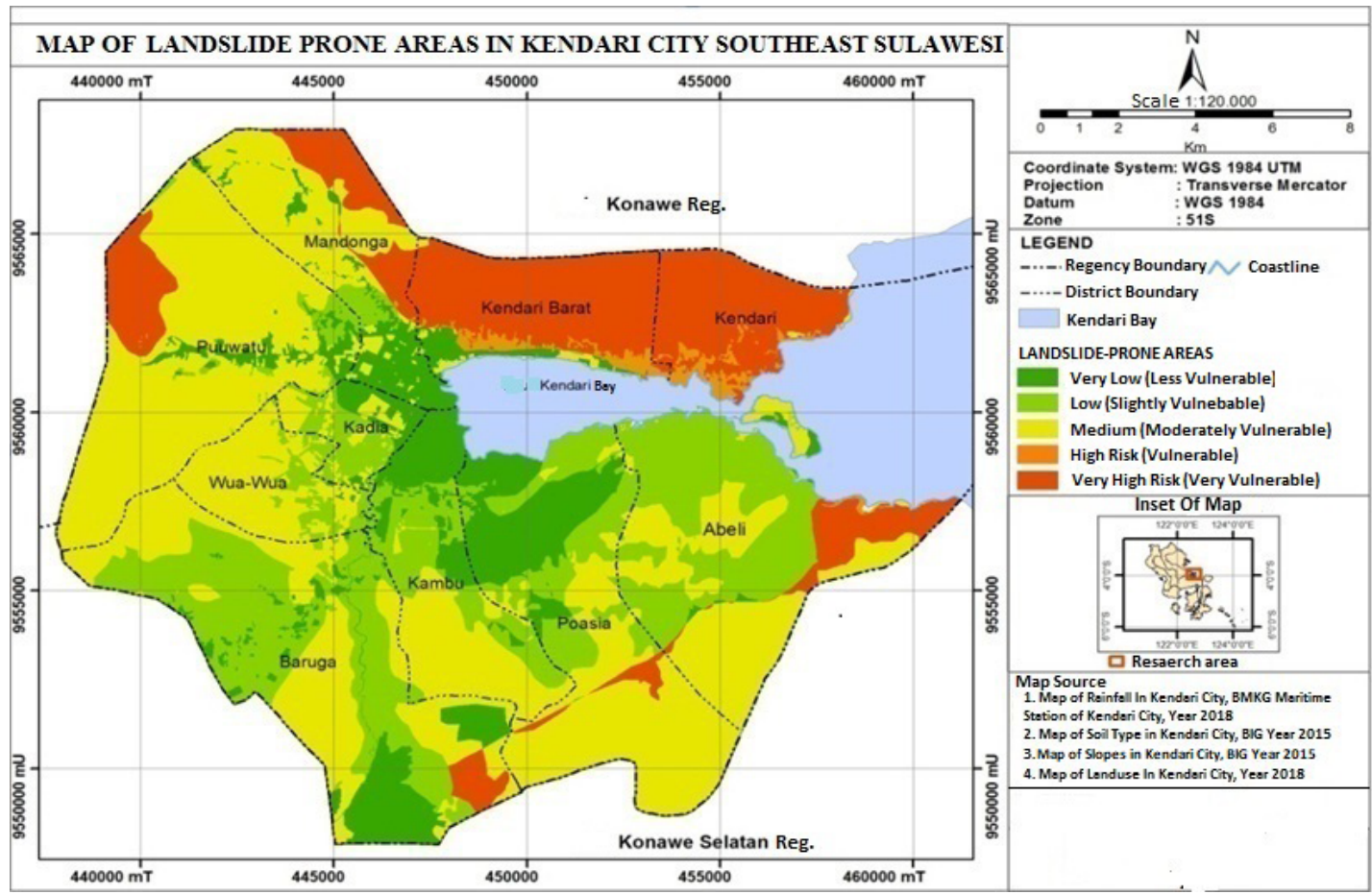

Figure 1. Landslide-Prone Areas Map of Kendari City 
The largest land use parameter in Kendari city is shrubs, which quantitatively estimated at $37.2 \%$. The shrubs weight was 30 , with a score of 0.38 , so the results of the multiplication of weights was 11.4. The second largest land use is agricultural land, at $36.81 \%$, with rice field accorded a weight of 30 and a score of 0.06 , so the results of the multiplication of weights was 1.8. According to Bartelletti et al. (2017), land use for building has a higher risk of landslides than that where vegetation is present.

The map overlay results from the four parameters above (rainfall, soil types, slope, and land use) were accumulated and categorized into five class intervals with respect to landslide vulnerability and quantified starting from a minimum of 9.6 to a maximum of 35.2, as shown in Table 5.

Figure 1 is a map showing the landslideprone zones in Kendari city determined from the four parameters.

\subsection{Discussion}

GIS-based landslide mapping using the overlay method with scoring and weighting generated the landslide-vulnerable zones. The Kendari City areas included in the low risk or slightly vulnerable category are most commonly found in the Kambu sub-district, Poasia sub-district, and Kadia sub-district. Most of Abeli sub-district and Poasia sub-district are residential areas. The most vulnerable category is found in the districts of Kendari, West Kendari, and Mandonga which have slopes above $25 \%$. According to Shahabi \& Hashim (2015), overlay was able to show the landslide susceptibility mapping in Cameron Highlands area in Malaysia. Figure 2 shows the percentage of landslide-prone zones in Kendari City.

Previous research has applied GIS with overlay in different locations. Shahabi \& Hashim (2015) employed GIS-based statistical models and remote sensing data with the overlay method to create a landslide susceptibility map in Cameron Highlands area of Malaysia, while Hadmoko et al. (2017) overlaid annual isohyets to establish the distribution of landslide occurrence in Java that increases in every interval class, and the highest in 25003000 mm. Hartono \& Nasikh (2017) employed map analysis using the intersect type of overlay with scoring to produce a landslide potency map of Batu-East Java. In addition, Kurnianto et al. (2018) produced a map of landslide-prone disaster zone in Jember-East Java using the application of GIS.

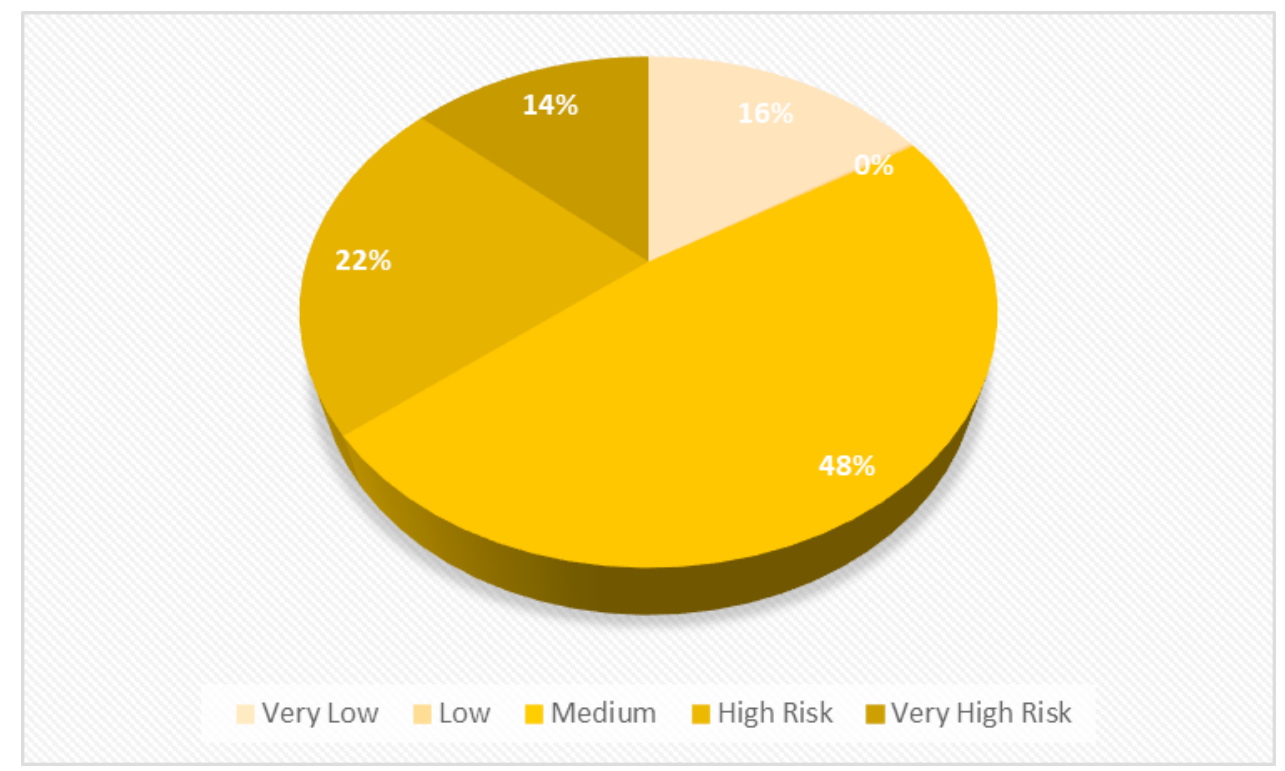

Figure 2. Percentage of Landslide Prone Areas in Kendari City 


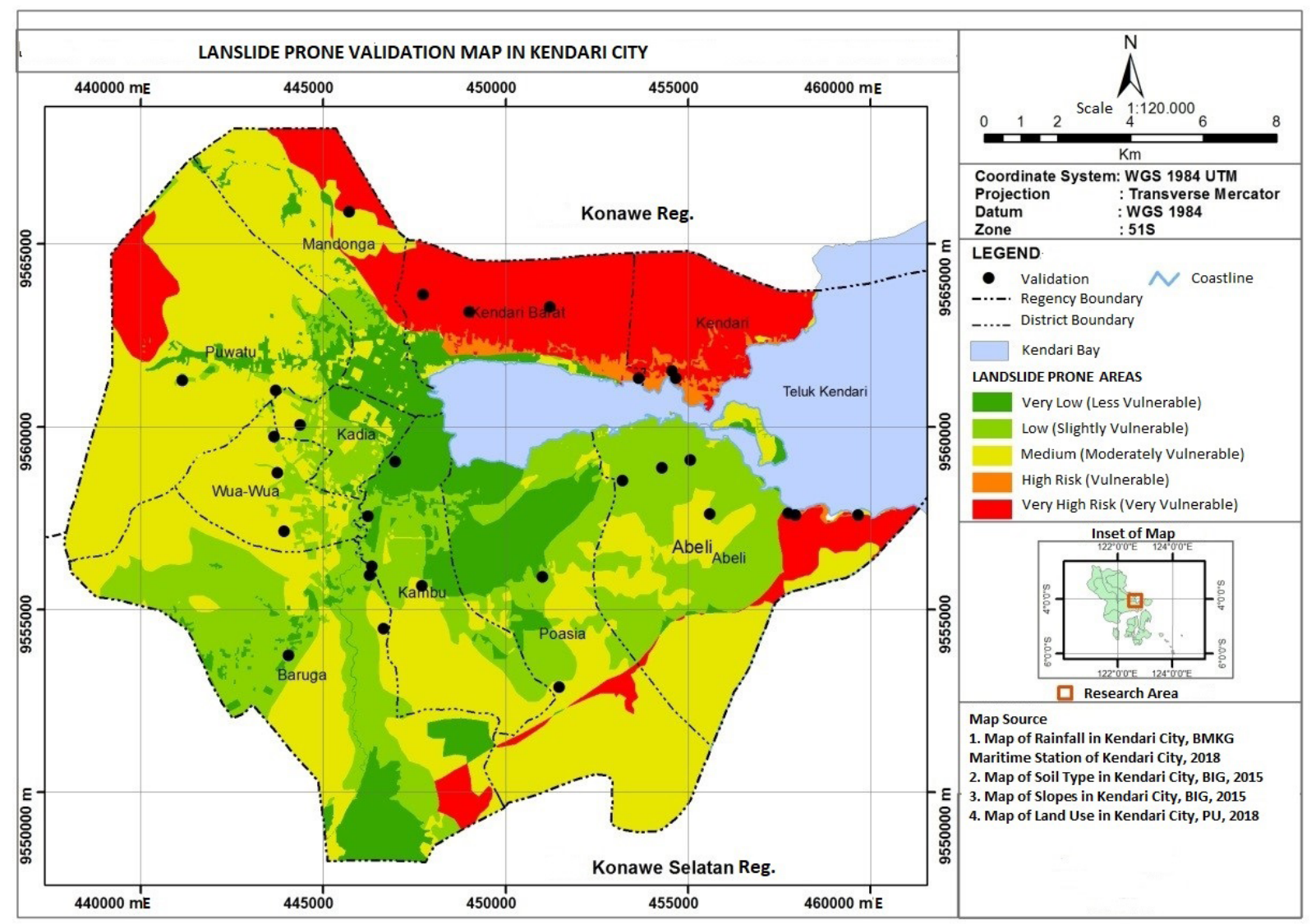

Figure 3. Validation of Landslide-Prone Areas Map in Kendari City

However, previous research has rarely compared actual condition with the map results. Most of them ended in the map result of GIS used overlay method. Hartono \& Nasikh (2017) focus on producing a landslide potency map with analysis of the causative factors of landslides, while Juang et al. (2019) focused on reporting previous landslide maps. Bartelletti et al. (2017) focused on developing a GIS landslide map from a landslide database, statistical analysis, geomorphological and geological maps.

The validation efforts are important in establishing the quality of GIS maps produced by researchers, and to establish the compatibility of the GIS-based landslide map with actual conditions. According to Guzzetti et al. (2012), map validation is a standard that is needed in landslide mapping.

The compatibility of the landslide-prone areas on the map and the situation on the ground was checked directly by taking several samples of field coordinates using the 2017 Public Disaster Report data obtained from the
Kendari City BPBD. According to Nurdin \& Kubota (2018), estimated landslide locations without field validation make the process less meaningful. Figure 3 is a map of the survey sample points for the purpose of validation of the landslide zone map with actual conditions.

Based on data from 2012, landslide-prone maps, and the 2017 General Disaster Report from Kendari City BPBD, 28 points were collected for validation, located in eight subdistricts. The research involved the plotting of sample areas using GPS, direct observation at the site, and interviews with family members at each location and BPBD members. Guzzetti et al. (2012) emphasize that interviews with landslide experts are an important way to obtain data on landslide-prone areas. According to Juang et al. (2019), interviews with community representatives also provide validation of landslides in a certain area.

The history of landslides was established through field interviews, as suggested by $\mathrm{Yi}$ et al. (2017). It was discovered that the 
highly vulnerable areas (Very High Risk) had experienced more than 33 landslides, while the vulnerable areas (High Risk) had experienced 17. As for the moderately vulnerable areas, they had experienced seven landslides, while the slightly vulnerable (Low Risk) areas had experienced landslides five times. The less vulnerable, Very Low Risk areas, experienced landslides only times.

The results of the field investigation showed that seven locations did not match the map, while 21 locations were compatible. This shows that the compatibility of the landslideprone map with actual condition in Kendari City is $75 \%$. Table 6 shows the results of field investigation.

These results reinforce of the results of the mapping of landslide-prone zones in Kendari City, and make the map suitable for publication as a guide in disaster preparedness against landslides. According to Hilman \& Sunaedi (2018), a highly accurate landslide map can improve community preparedness and reduce the impact of disasters.

Table 6. Field Check Results

\begin{tabular}{|c|c|c|c|c|c|c|c|}
\hline \multirow{2}{*}{ Nu. } & \multirow{2}{*}{ Sub-district } & \multirow{2}{*}{ Village } & \multicolumn{2}{|c|}{ Coordinate } & \multirow[t]{2}{*}{ Risk Category } & \multirow[t]{2}{*}{ Compatibility } & \multirow[t]{2}{*}{ Value } \\
\hline & & & $X$ & $Y$ & & & \\
\hline 1 & Baruga & Watubangga & 446206 & 9555942 & Low & No & 0 \\
\hline 2 & Baruga & Baruga & 446111 & 9555688 & Low & No & 0 \\
\hline 3 & Baruga & Wundudopi & 446524 & 9554260 & Medium & Yes & 1 \\
\hline 4 & Baruga & Lepo-lepo & 443889 & 9553529 & Low & Yes & 1 \\
\hline 5 & Kambu & Padaleu & 447572 & 9555434 & Medium & Yes & 1 \\
\hline 6 & Kambu & Lalolara & 446111 & 9557339 & Very Low & Yes & 1 \\
\hline 7 & Kambu & Kambu & 446905 & 9558768 & Very Low & Yes & 1 \\
\hline 8 & Poasia & Anggoeya & 450842 & 9555752 & Low & Yes & 1 \\
\hline 9 & Poasia & Andounuhu & 451286 & 9552704 & Medium & Yes & 1 \\
\hline 10 & Abeli & Abeli & 453128 & 9558292 & Low & Yes & 1 \\
\hline 11 & Abeli & Anggolomelai & 454176 & 9558673 & Low & No & 0 \\
\hline 12 & Abeli & Petoaha & 454938 & 9558832 & Low & No & 0 \\
\hline 13 & Abeli & Anggolomelai & 455446 & 9557403 & Low & No & 0 \\
\hline 14 & Abeli & Sambuli & 457637 & 9557435 & High & Yes & 1 \\
\hline 15 & Abeli & Sambuli & 457827 & 9557435 & High & Yes & 1 \\
\hline 16 & Abeli & Tondonggeu & 459542 & 9557371 & Very High & Yes & 1 \\
\hline 17 & Puuwatu & Puuwatu & 440999 & 9560991 & Low & Yes & 1 \\
\hline 18 & Puuwatu & Punggolaka & 443571 & 9560832 & Medium & Yes & 1 \\
\hline 19 & Wua-wua & Anawai & 443476 & 9559594 & Medium & Yes & 1 \\
\hline 20 & Wua-wua & Wua-wua & 443603 & 9558514 & Medium & No & 0 \\
\hline 21 & Wua-wua & Wua-wua & 443762 & 9556927 & Medium & No & 0 \\
\hline 22 & Mandonga & Wawombalata & 445603 & 9565658 & High & Yes & 1 \\
\hline 23 & Kendari Barat & Kemaraya & 447667 & 9563372 & Very High & Yes & 1 \\
\hline 24 & Kendari Barat & Watu-watu & 448842 & 9562927 & Very High & Yes & 1 \\
\hline 25 & Kendari Barat & Punggaloba & 451096 & 9563054 & Very High & Yes & 1 \\
\hline 26 & Kendari Barat & Kandai & 453477 & 9561118 & High & Yes & 1 \\
\hline 27 & Kendari & Kendari Caddi & 454366 & 9561308 & High & Yes & 1 \\
\hline 28 & Kendari & Kampung Salo & 454525 & 9561149 & High & Yes & 1 \\
\hline & $\sum$ & & & & & & 21 \\
\hline
\end{tabular}




\section{Conclusion}

Based on the map of landslide-prone area distribution using GIS, it was discovered that most of Kendari city, or $86.5 \%$, was in the Low Risk to the Very High Risk categories, representing slightly vulnerable to very vulnerable areas. The areas that were Very Low category, or less vulnerable to landslides, constituted only $13.5 \%$ of the total. The level of compatibility of landslide-prone map in Kendari city with actual conditions was $75 \%$, which shows that the map resulting from GIS spatial analysis can be used in mapping the level of landslide vulnerability in Kendari city.

\section{Acknowledgements}

This work was supported by the management of Universitas Sembilanbelas November Kolaka, Universiti Tun Hussein Onn Malaysia, and Universitas Halu Oleo. Thanks to the Kendari city BPBD and Kendari city people, especially Muhammadiyah people, who were pro-active village officials in the interviews.

\section{References}

Amaluddin, L. O., Sejati, A. E., Ihsan, F. A., \& Mutiana, M. (2019). Identification of huntete beach tourism object in Kulati village East Tomia sub-district Wakatobi regency. Geosfera Indonesia. Vol. 3, No. 3, pp. 43-49. https://doi.org/10.19184/geosi.v3i3.8688

Atmojo, S. E., Rusilowati, A., Dwiningrum, S. I. A., \& Skotnicka, M. (2018). The reconstruction of disaster knowledge through thematic learning of science, environment, technology, and society integrated with local wisdom. Jurnal Pendidikan IPA Indonesia. Vol 7, No. 2, pp. 204213. https://doi.org/10.15294/jpii.v7i2.14273

Bartelletti, C., Giannecchini, R., D’Amato Avanzi, G., Galanti, Y., \& Mazzali, A. (2017). The influence of geological-morphological and land use settings on shallow landslides in the Pogliaschina T. Basin (northern apennines, Italy). Journal of Maps. Vol. 13., No. 2, pp. $142-$ 152. https:// doi.org/10.1080/17445647.2017.1279082

BNPB. (2019). Data Informasi Bencana Indonesia (DIBI) 2019. Retrieved from https://bnpb.cloud/ dibi/laporan5a

Dawood, H. (2011). Theories of interval arithmetic: mathematical foundations and applications. Lambert Academic.

Dawood, H., \& Dawood, Y. (2019). Parametric Intervals: More Reliable or Foundationally Problematic? October. Retrieved from https:// doi.org/10.5281/zenodo.3234186

Guzzetti, F., Mondini, A. C., Cardinali, M., Fiorucci, F., Santangelo, M., \& Chang, K. T. (2012). Landslide inventory maps: New tools for an old problem. In Earth-Science Reviews. Vol. 112, No. 1-2, pp. 42-66. https:/ / doi.org/10.1016/j.earscirev.2012.02.001

Hadmoko, D. S., Lavigne, F., Sartohadi, J., Gomez, C., \& Daryono, D. (2017). Spatio-Temporal Distribution of Landslides in Java and the Triggering Factors. Forum Geografi. Vol. 31, No. 1, pp. 1-15. https:// doi.org/10.23917/ forgeo.v31i1.3790

Hartono, R., \& Nasikh. (2017). Applying remote sensing technology and geographic information system in Batu, East Java. Indonesian Journal of Geography. Vol. 49, No. 2, pp. 118-124. https:/ / doi.org/10.22146/ijg.12842

Hilman, I., \& Sunaedi, N. (2018). Revitalization of local wisdom for the environmental education. Geosfera Indonesia. Vol 2, No. 1, pp. 19. https:/ / doi.org/10.19184/geosi.v2i1.7459

Huang, A., Bin, Lee, J. T., Ho, Y. Te, Chiu, Y. F., \& Cheng, S. Y. (2012). Stability monitoring of rainfall-induced deep landslides through pore pressure profile measurements. Soils and Foundations. Vol. 52, No. 4, pp. 737-747. https://doi.org/10.1016/j.sandf.2012.07.013 
Juang, C. S., Stanley, T. A., \& Kirschbaum, D. B. (2019). Using citizen science to expand the global map of landslides: Introducing the cooperative open online landslide repository (coolr). PLOS ONE. Vo. 14, No. 7, pp. 1-28. https://doi.org/10.1371/journal.pone.0218657

Kovács, I. P., Czigány, S., Dobre, B., Fábián, S., Sobucki, M., Varga, G., \& Bugya, T. (2019). A field survey-based method to characterise landslide development: A case study at the high bluff of the Danube, South-central Hungary. Landslides. Vol. 16, No. 8, pp. 1567-1581. https:// doi.org/10.1007/s10346-019-01205-8

Kurnianto, F. A., Apriyanto, B., Nurdin, E. A., Ikhsan, F. A., \& Fauzi, R. Bin. (2018). Geographic information system (gis) application to analyze landslide prone disaster zone in Jember regency East Java. Geosfera Indonesia. Vol. 2, No. 1, pp. 45-53. https://doi.org/10.19184/ geosi.v2i1.7524

Mueller, C. S., Briggs, R. W., Wesson, R. L., \& Petersen, M. D. (2015). Updating the usgs seismic hazard maps for Alaska. Quaternary Science Reviews. Vol. 113, pp. 39-47. https://doi. org/10.1016/j.quascirev.2014.10.006

Najib, N., Karnawati, D., \& Sudarno, I. (2015). Influence of geological condition towards slope stability on landslide: case study in Tengklik village, Tawangmangu district, Karanganyar regency, Central Java Province, Indonesia. Journal of Applied Geology. Vol 2, No. 3. pp. 217224 https:// doi.org/10.22146/jag.7265

Nurdin, P. F., \& Kubota, T. (2018). Gis-based landslide susceptibility assessment and factor effect analysis by certainty factor in upstream of Jeneberang river, Indonesia. Geoplanning: Journal of Geomatics and Planning. Vol. 5, No. 1, pp. 75-90. https://doi.org/10.14710/ geoplanning.5.1.75-90

Nursalam, L. O., Arisona, A., Ramli, R., Harudu, L., Kasmiati, S., Harianto, E., Ikhsan, F. A., \& Sejati, A. E. (2019). Mapping of subsurface geological structure and land cover using microgravity techniques for geography and geophysic surveys: A case study of Maluri Park, Malaysia. Geosfera Indonesia, 4(3), 280-290. https://doi.org/10.19184/geosi.v4i3.13738

Purba, J. O., Subiyanto, S., \& Sasmito, B. (2014). Pembuatan peta zona rawan tanah longsor di kota semarang dengan melakukan pembobotan parameter. Jurnal Geodesi Undip, 3(2), 40 52. Retrieved from https://ejournal3.undip.ac.id/index.php/geodesi/article/view/5205

Qarinur, M. (2015). Landslide runout distance prediction based on mechanism and cause of soil or rock mass movement. Journal of the Civil Engineering Forum. Vol 1, No. 1, pp. 29-36. https:/ / doi.org/10.22146/jcef.22728

Rahman, A. ur, Khan, A. N., \& Collins, A. E. (2014). Analysis of landslide causes and associated damages in the Kashmir Himalayas of Pakistan. Natural Hazards. Vol. 71, No. 1, pp. 803821. https://doi.org/10.1007/s11069-013-0918-1

Ruiz-Villanueva, V., Allen, S., Arora, M., Goel, N. K., \& Stoffel, M. (2017). Recent catastrophic landslidelakeoutburstfloodsintheHimalayanmountain range. Progressin Physical Geography: Earth and Environment. Vol. 41, No. 1, pp. 3-28. https://doi.org/10.1177/0309133316658614

Shahabi, H., \& Hashim, M. (2015). Landslide susceptibility mapping using GIS-based statistical models and Remote sensing data in tropical environment. Scientific Reports. Vol. 5, No. 1, pp. 1-15. https://doi.org/10.1038/srep09899

Suwarno, S., Sartohadi, J., Sunarto, S., \& Sadharto, D. (2016). A Review of Society's Behaviour Towards Land Management of Susceptible Area to Landslide in Pekuncen, Banyumas. Forum Geografi. Vol 30, No. 1, pp. 99-105. https:/ / doi.org/10.23917/forgeo.v30i1.1704 
Yi, X., Chen, C., Liu, L., Huang, L., Chen, J., \& Zhou, W. (2017). Prediction of GNSS TEC based on improved BP neural network. Fifth Recent Advances in Quantitative Remote Sensing, pp. $443-448$ 